\title{
MJN THE RELATIONSHIP BETWEEN PHYSICAL AND VERBAL ABUSE AND PSYCHOLOGICAL HEALTH STATUS AMONG SAUDI HOSPITAL NURSES
}

\author{
Saad Aqeel Al-shammari" ${ }^{*}$, Muneeb Alzghool ${ }^{2}$ \\ ${ }^{1}$ Regional Nursing Administration, Ministry of HealthDirectorate of Health Affairs, Hafer Albatin, Saudi \\ Arabia \\ ${ }^{2}$ Department Community and Mental Health Nursing, King Saud University, College of Nursing, Riyadh, \\ Saudi Arabia
}

*Corresponding Author’s Email: saadalshsmary@gmail.com

\begin{abstract}
Background: Recently, there were significant challenges in the health care system, including abuse among nurses. This concern has sought more attention because of its negative consequences on the organization, the nurses' psychological health status, and the delivery of care to the patients. Objectives: This study primarily aimed to determine the presence of physical and verbal abuse and its effect on the nurses' mental health status. Methods: A cross-sectional survey was conducted to determine the incidence of abuse experienced or witnessed by nurses in the Hafer-Albatain City of Saudi Arabia. Three hundred seventy nurses were recruited from five hospitals and voluntarily answered a standardized questionnaire about physical and verbal abuse, depression, anxiety, and stress. Data gathering was completed from January to March 2019. Data analysis was performed using Statistical Package for Social Sciences Ver. 21. Results: The study's findings showed that nurses commonly experienced verbal abuse $(52.7 \%)$ compared to physical abuse (34.3\%). Regarding mental health status, results showed that anxiety and depression were higher than stress, respectively. However, $21.4 \%$ have mild stress, $32.7 \%$ have moderate anxiety, and $27.6 \%$ have mild depression. Conclusion: The study proved that reported physical abuse $(66.40 \%)$ is significantly attributed to hospital conditions variations. The variance is even higher when associated with reported cases of verbal abuse (98.4\%). Among the three mental health status components, only stress was found significantly correlated with the hospital setting and job experience.
\end{abstract}

Keywords: Physical Abuse, Verbal Abuse, Depression, Anxiety, Stress, Nurses

\section{INTRODUCTION}

Workplace abuse is a global problem among healthcare workers (Al-Shamlan et al., 2017). About 10$50 \%$ of health care workers experience physical and verbal abuse every year. The nurses reportedly experienced unacceptable verbal abuse and violence (Al-Shamlan et al., 2017). Based on the Robert Wood Johnson Foundation (2015), abuse among nurses has become an epidemic. It has grown more attention because of its consequences to the delivery of care and the organization (Alkhorashy \& Al Moalad, 2016). Abuse may lead to permanent disability or even death.
From 2005 to 2014, the United States showed a dramatic increase in violent incidents against health care workers in private hospitals (National Nurses United, 2016). Workplace abuse should not be considered a typical experience among the organization's professionals and should not be regarded as part of its cultural practice (Campbell, 2016). It should be perceived as an alarming experience that everyone must surpass (Brous, 2018).

After a threatening experience, the individuals' psychological adjustment is associated with their cognitive ability to process knowledge and develop adaptive strategies (Grossman et al., 2000). Efficient 
coping strategies are associated with a person's perspective towards a negative, unexpected, or threatening event. It was further exerted that abuse must be scientifically investigated (Fjelland et al., 2017). The distribution of physical and verbal abuse among nurses varies widely. The abuse among health care workers in Australia, Turkey, and United States were $50 \%, 72 \%$ and $37 \%$ (Hegney et al., 2003). Moreover, these nurses experienced at least one episode of either threat, sexual harassment, or verbal abuse. Over 13\% nurses claimed that they experienced at least one episode of physical assault.

Abuse is also reported as an alarming issue in several Middle East regions such as Jordan with 37\% and Lebanon with $10 \%$ of nurses experienced various verbal abuse (Ahmed, 2012; Alameddine, Mourad \& Dimassi, 2015). Moreover, two Saudi Arabia studies reported $28 \%$ and $45 \%$ as the rate of violence (Al-Turki, Afify \& AlAteeq, 2016; El-Gilany, El-Wehady \& Amr, 2010).

Physical violence is a physical force such as beating, kicking, slapping, stabbing, shooting, pushing, biting, and pinching against another person or group. Psychological violence includes verbal abuse, bullying/ mobbing, harassment, and a person's threatening. Both forms of violence were considered harmful to the individual (World Health Organization, 2002). The effect of abuse on nurses includes burnout, anxiety, helplessness, job dissatisfaction, and diminished quality of care (Rowe \& Sherlock, 2005; Franz et al., 2010; Kamchuchat et al., 2008).

Studies showed that nurses' level of anxiety to violence and their skills and behavior during the crisis were also contributors to violence (Chen et al., 2008; Pai \& Lee 2011). Local studies showed some findings of depression, anxiety, and stress among nurses. Depression and anxiety among nurses were assessed in Saudi Arabia, which led that 53\% do not have anxiety, $27 \%$ were classified under the cause of concern, and 20 $\%$ were diagnosed with clinical cases. About $75 \%$ were not depressed, $15 \%$ probable cause concern, and 10\% were with probable clinical cases (Abbas et al., 2012). A study in a region in Saudi Arabia showed that critical care nurses have mild anxiety levels. The most common reported symptoms were anxious mood, tension, insomnia, somatic symptoms, and fear. Demographic factors associated with depression, anxiety, and stress among nurses were explored in previous Saudi Arabia studies (Ahmed, 2015). In Riyadh, the study showed that anxiety is common among those nurses aged less than 30 years, whereas depression among 30 to less than 40 years (Ahmed, 2015). Abbas et al., (2012) explained that nurses from the middle east have higher anxiety and depression levels than nurses from other regions. Physical activity and smoking were also significantly associated with anxiety and depression among nurses (Abbas et al., 2012). Ahmed (2015) found out that anxiety levels were significantly correlated with the age among critical care nurses in Saudi Arabia.

In the status quo, there are many reasons for exploring workplace violence among nurses and its effects. First, workplace violence has been reported to have a rising rate in health care facilities. This experience has been recognized as a prime problem for nurses and other health care providers (Fute et al., 2015). Second, it has been shown in several studies that there are adverse effects of workplace violence. According to Hesketh (2003), by becoming aware of how the working environments affect patient outcomes and nurses and health care professional's retention, it is time for researchers and nurse scientists to explore and talk about the impact of workplace violence in hospitals. Therefore, this study is a significant response to the needed attention to shed light on empirical factors and effects of workplace violence. Third, there were a few studies that examined the presence of workplace violence among nurses in the practice settings in Saudi Arabia. There were only a few studies that investigated workplace violence forms, such as verbal and physical abuse on the health status of the nurses (Al-Shamlan et al., 2017).

Thus, this study not only realizes the need to investigate workplace violence among nurses in clinical settings but also aims to explore the need to derive implications to advocacies and policies towards forms of abuse among nurses. Therefore, this study aims to determine the relationship between verbal and physical abuse with nurses' psychological health status and examined the association of demographic factors with physical and verbal abuse.

\section{METHODOLOGY}

\section{Research Design}

This study used a descriptive cross-sectional survey wherein it examined the relationship between verbal and physical abuse, demographic characteristics, and its effect on local nurses' mental health status in selected hospitals in Hafer-Albatain in Saudi Arabia. 


\section{Setting}

The researcher surveyed several hospitals in HaferAlbatain, Saudi Arabia. The hospitals' selection was made through convenience sampling, which included those which are under the supervision of the Ministry of Health and the approval of the administrators of the organization.

\section{Study Population and Sampling}

The total population of nurses from the selected hospitals was collected from the human resource or the nursing department. Then, the sample size was calculated based on the total population. The study used $\mathrm{G}$ power analysis with a confidence interval of $95 \%$ and a $5 \%$ margin of error to determine the sample size. The calculation of sample size was done per hospital population of nurses. Each of the hospitals was distributed with exceeding five questionnaires from the calculated sample size. Convenience sampling was used whereby there might be drop-outs, invalid returned tools, and others. Tools returned with incomplete and invalid answers were disregarded. Convenience sampling, a type of non-probability sampling, was used in the selection of respondents. Eligible respondents were selected based on the inclusion criteria. These criteria included Saudi nurses with a contract to work in the selected hospital and have a nursing license. The respondents who either claimed or not claimed has experienced or witnessed abuse or violence at work were the final respondents for the data analysis. Exclusion criteria are temporary nurses (if any) or those who do not perform direct patient care. The final number of samples was 108 from Hospital A, 84 from Hospital B, 69 from Hospital C, 62 from Hospital D, and 47 for Hospital E. The response rates are $97.3 \%$ for A, $97.7 \%$ for $\mathrm{B}, 94.5 \%$ for $\mathrm{C}, 95.4 \%$ for $\mathrm{D}$ and $88.7 \%$ for $\mathrm{E}$. The total number of respondents is 370 .

\section{The Procedure of Data Collection}

The approval letter from the Institutional Review Board was attached and sent to the settings for the conduct of research. The response for approval from the settings was secured for data collection. Recruitment of participants was done with the assistance of the unit administrators. Nurses were invited through posters posted on boards and by verbal invitations. Eligible and selected respondents were oriented of the purpose and their rights as respondents. The pen and paper methods were used in data gathering. The respondents answered the questionnaire and sealed with envelopes when finished. The envelopes with the questionnaire were dropped in designated boxes. This method was used to preserve confidentiality and anonymity among the respondents. Missing and invalid responses were identified and considered invalid. The valid instruments were used as a basis in the calculation of the response rate.

\section{Research Instrument}

The instrument is composed of four parts. The first part of the questionnaire gathered the personal and workplace data of the nurses. The variables included age, gender, marital status, years of working experience in the hospital, work time, work shift, working hours, interaction with patients, physical contact, type of patients, the gender of the patient, type of specialties, worries to abuse, reporting procedure, encouragement to report, and the person assigned in reporting. Part A in the tool included items PD 1 to 13.1 with 17 items, including secondary questions. The second part of the questionnaire assessed physical abuse. The questions asked for the abuse experienced by the respondents within 12 months from the period of data gathering. It assessed the description of the incident, occurrence, abuser, place, time, day, and response. It also explored the respondents' perception if the abuse is preventable, causes and the need for treatment to the injury, causes and duration of leave from work, employers' response, satisfaction to management to abuse, and the reasons for not reporting the abuse. For those who did not experience but witnessed abuse, this part asked how often they witnessed abuse and whether they reported the case. The items specific to physical abuse were found in Part B PV 1.1 to 2.1 items in the data gathering tools. Part B is composed of 20 items with secondary questions. Items in Part B with 1, 1.2, 1.8, 1.9. 1.9.1., $1.10,1.11,1.12,1.13,2$, and 3 were answerable by yes or no, while others with don't know. Items 1.1, 1.3, 1.4, $1.5,1.6,1.10 .1,1.14$, and 2.1 used multiple-choice questions whereby respondents can only select one from the available options. The remaining items such as 1.7 and 1.15 used select-all-that-apply questions, whereby respondents can tick all options applicable to their experience with physical abuse. The third part asked for the verbal abuse experience. The items included Part C VA 1 to 10 on the data gathering tool in this study. Part C is composed of 13 items with secondary questions. Items 1,6 , and 8 used yes or no questions, whereas item 7 added the "don't know" option. Items 2, 3, 4, and 9 
used multiple-choice questions, whereas respondents can select one among the available options. Items 7.1, 10 , and 5 followed select-all-that-apply questions whereby respondents can check all the options applicable to their verbal abuse experience. Lastly, the fourth assessed depression, anxiety, and stress using the Depression, Anxiety, and Stress Scale - 21 (DASS-21). This tool is a set of three self-report scales designed to measure the negative emotional states of depression, anxiety, and stress. The DASS-21 is a short version of the original 42-item questionnaire and consists of 21 items in three scales: depression (DASS-D), anxiety (DASS-A), and stress (DASS-S). The items were scored on a 4-point Likert-type scale, whereby 0 as the lowest and three as the highest. Score 0 means did not apply all to the respondents, whereas the highest three means applied very much most of the time. The total scores for each scale were multiplied by the sum of 2 . Each scale's possible range is from 0 to 42 , with higher scores indicating more depression, anxiety, and stress. The questionnaire used in this study is the Arabic version, which was validated and tested for internal consistency in previous studies with a Cronbach alpha of 0.931 (Aljuhaili \& Alzghool, 2020). In the tool, items $1,6,8,10,14$ and 18 pertains to stress. In anxiety, items $2,4,7,9,15,19$ and 20 are included. The depression is measured with items $3,5,11,12,13,16,17$ and 21 in the DAS-21 tool.

\section{Ethical Considerations}

Approval for the study's ethical conduct was secured from the Institutional Review Board (IRB) of King Fahad Medical City (KFMC). The informed consent process was followed up. The nurses who gathered the data were briefed on securing informed consent, briefing the respondents, and addressing concerns in answering the instruments. The nurses who were oriented to conduct the survey were also asked to help them recruit prospective participants. The objectives were explained, and implied consents were provided by those who voluntarily participated in the survey. Anonymity was explained and was assured by not including participants' names in the questionnaire. Confidentiality of the responses was also presented that only the answers' codes were used to process and analyze the survey results. The participants were informed that they have the right to withdraw from the study at any time without any consequences. Questionnaires were distributed to those who willingly and voluntarily consented to participate in the research and were retrieved after they finished answering.

\section{Data Analysis}

The respondents who answered "no" in either physical or verbal abuse were removed for data analysis. In analyzing, descriptive statistics was used in presenting the characteristics of participants, abuse experience and DASS-21. Association was measured using Eta which wherein the percent variability in the dependent variable explained either linearly or nonlinearly with the independent variable. The main reason or justification why Eta was used because of the available data, level of measurement and the objectives. With these on hand, the interpretation requires that the dependent variable be interval in level and the independent variable be categorical (nominal, ordinal, or grouped interval). The research doesn't find any viable reasons why there is a need for other statistical tests which will just complicate the analysis whereby eta can provide variations in the responses and when considering the level of measurements. Using Pearson correlation nor Analysis of Variance will just complicate the analysis considering that the variables are not all with the same type of level of measurements nor the options are the same as that of a Likert Scale. The questionnaire shows that the options are varied whereas some items are answerable by yes or no, other items by multiple choice options, and other items included select all that apply. In interpreting the Eta 2 value of 0.20 means that the independent variable explains $20 \%$ of the variance in the dependent variable. Data were processed using IBM SPSS Statistics for Windows V.21 (Armonk, NY: IBM Corp. 201).

\section{RESULTS}

\section{Profile of the Respondents}

Table 1 below summarizes the demographic profile of the respondents according to six variables. Nearly $30 \%$ of the participants hailed from A. Those from the Hospital E comprise only $12.7 \%$ of the total number which is the least samples included in the survey. Most of those who participated $43.2 \%$ were aged 30 to 34 years age. In terms of Marital Status, sixty-five percent of them were married with twenty-seven percent were single. Based on job experience, majority has worked as nurse from one to ten years already with percentage share of $32.7 \%$ and $36.5 \%$ respectively. Almost all of them were full time nurses at $95.9 \%$. 
Table 1: Demographic Profile of the Respondents

\begin{tabular}{|c|c|c|c|}
\hline & & $n$ & $\%$ \\
\hline \multirow[t]{5}{*}{ 1. Hospital } & Hospital A & 108 & 29.2 \\
\hline & Hospital B & 84 & 22.7 \\
\hline & Hospital C & 69 & 18.6 \\
\hline & Hospital D & 62 & 16.8 \\
\hline & Hospital E & 47 & 12.7 \\
\hline \multirow[t]{9}{*}{ 2. Age } & 19 below & 0 & 0 \\
\hline & $20-24$ & 20 & 5.4 \\
\hline & $25-29$ & 109 & 29.5 \\
\hline & $30-34$ & 160 & 43.2 \\
\hline & $35-39$ & 59 & 15.9 \\
\hline & $40-44$ & 18 & 4.9 \\
\hline & $45-49$ & 1 & 0.3 \\
\hline & $50-54$ & 2 & 0.5 \\
\hline & $55-59$ & 1 & 0.3 \\
\hline \multirow[t]{2}{*}{ 3. Gender } & Male & 201 & 54.3 \\
\hline & Female & 169 & 45.7 \\
\hline \multirow[t]{5}{*}{ 4. Marital Status } & Single & 102 & 27.6 \\
\hline & Married & 241 & 65.1 \\
\hline & Living with partner & 0 & 0.0 \\
\hline & Separated & 24 & 6.5 \\
\hline & Widow/widower & 3 & 0.8 \\
\hline 5. Job & Nurses & 370 & 100 \\
\hline \multirow[t]{6}{*}{ 6. Job Experience } & Under 1 & 23 & 6.2 \\
\hline & 1 to 5 & 121 & 32.7 \\
\hline & 6 to 10 & 135 & 36.5 \\
\hline & 11 to 15 & 79 & 21.4 \\
\hline & 16 to 20 & 6 & 1.6 \\
\hline & over 20 & 6 & 1.6 \\
\hline \multirow[t]{3}{*}{ 7. Job Shift } & Full time & 355 & 95.9 \\
\hline & Part time & 13 & 3.5 \\
\hline & Temporary/casual & 2 & 0.5 \\
\hline
\end{tabular}

Physical and Verbal Abuse, Depression, Anxiety, and Stress

Based on table 2, more than fifty percent (52.7\%) of the participants reported experiencing verbal abuse compared to $35.7 \%$ for physical abuse. On the other hand, for stress, reported incidents or episodes of stress were $21.4 \%$ and $8.1 \%$ respectively for mild and moderate stress. In this population, those who reported to have experienced extremely severe to severe anxiety were at $14.3 \%$ and $4.1 \%$, respectively. For depression only $4.6 \%$ of the population had severe depression while more than half reported mild to moderate levels at $27.6 \%$ and $24.3 \%$. The overall reported incidence of stress is $29.5 \%$, depression is $56.5 \%$ and anxiety is $63.0 \%$.

Table 2: Frequency and Percentage Distribution of Participants Who have Self-Reported Physical and Verbal Abuses, Stress, Anxiety, and Depression

\begin{tabular}{|c|c|c|c|}
\hline & & $n$ & $\%$ \\
\hline \multirow[t]{2}{*}{ Physical Abuse } & No & 238 & 64.3 \\
\hline & Yes & 132 & 35.7 \\
\hline \multirow[t]{2}{*}{ Verbal Abuse } & No & 175 & 47.3 \\
\hline & Yes & 195 & 52.7 \\
\hline \multirow[t]{3}{*}{ Stress } & Normal & 261 & 70.5 \\
\hline & Mild & 79 & 21.4 \\
\hline & Moderate & 30 & 8.1 \\
\hline \multirow[t]{5}{*}{ Anxiety } & Normal & 137 & 37.0 \\
\hline & Mild & 44 & 11.9 \\
\hline & Moderate & 121 & 32.7 \\
\hline & Severe & 53 & 14.3 \\
\hline & Extremely Severe & 15 & 4.1 \\
\hline \multirow[t]{4}{*}{ Depression } & Normal & 161 & 43.5 \\
\hline & Mild & 102 & 27.6 \\
\hline & Moderate & 90 & 24.3 \\
\hline & Severe & 17 & 4.6 \\
\hline
\end{tabular}

Physical abuse was experienced by around one third of the respondents which is equivalent to $35.7 \%$ of the study population. Most of those abuses were committed even without weapons, which is something that is noteworthy. In comparison, those who were 
physically abused with weapons at hand comprise $6.4 \%$ of the population. A little more than $13 \%$ of the population believes that workplace abuses are already becoming typical incidents in the hospital, and that usual perpetrators are the patients themselves (13.7\%) and their relatives $(15.4 \%)$. For 118 of the respondents (equivalent to $31.8 \%$ ) of the population, the physical abuses were committed against them inside the hospital premises. For those who were abused, the incidents happen almost any time of the day and any day of the week. In response to the abuses but majority cannot exactly remember the period. The respondents said they sought the help of the union (14.6\%). For some, they resorted to physically defending themselves (13.8\%). For those who experienced abuse, half of them said that these abuses could not have been prevented (18.3\%) (See Table 3).

\section{PhysicalAbuse}

Table 3: Physical Abuses Experienced by the Respondents

\begin{tabular}{|c|c|c|c|}
\hline & & Freq. & Per. \\
\hline \multirow{2}{*}{$\begin{array}{l}\text { In the last } 12 \text { months, have } \\
\text { you been physically attacked } \\
\text { in your workplace? }\end{array}$} & Yes & 132 & 35.7 \\
\hline & No & 238 & 64.3 \\
\hline \multirow{2}{*}{$\begin{array}{l}\text { If yes, please think of the last } \\
\text { time that you were physically } \\
\text { attacked in your place of } \\
\text { work. How would you } \\
\text { describe this incident? }\end{array}$} & Abuse w/out weapon & 108 & 29.1 \\
\hline & Abuse with weapon & 24 & 6.4 \\
\hline \multirow{2}{*}{$\begin{array}{l}\text { Do you consider this to be a } \\
\text { typical incident of physical } \\
\text { abuse in your workplace? }\end{array}$} & Yes & 50 & 13.5 \\
\hline & No & 82 & 22.1 \\
\hline \multirow[t]{5}{*}{ Who attacked you? } & Patient & 51 & 13.7 \\
\hline & Relatives & 57 & 15.4 \\
\hline & Public & 18 & 4.9 \\
\hline & Colleague/staff & 5 & 1.4 \\
\hline & Manager & 1 & 0.3 \\
\hline \multirow{3}{*}{$\begin{array}{l}\text { Where did the incident take } \\
\text { place? }\end{array}$} & Inside & 118 & 31.8 \\
\hline & Outside & 4 & 1.1 \\
\hline & patients' home & 10 & 2.7 \\
\hline \multirow{5}{*}{$\begin{array}{l}\text { At which time of day did it } \\
\text { happen? }\end{array}$} & $7: 00$ to before $13: 00$ & 26 & 7 \\
\hline & $13: 00$ - before $18: 00$ & 20 & 5.4 \\
\hline & 18:00-before $24: 00$ & 27 & 7.3 \\
\hline & $24: 00$ - before $7: 00$ & 13 & 3.5 \\
\hline & Don't remember & 46 & 12.4 \\
\hline
\end{tabular}

\begin{tabular}{|c|c|c|c|}
\hline \multirow{8}{*}{$\begin{array}{l}\text { Which day of the week did it } \\
\text { happen? }\end{array}$} & Monday & 7 & 1.9 \\
\hline & Tuesday & 15 & 4 \\
\hline & Wednesday & 14 & 3.8 \\
\hline & Thursday & 11 & 3 \\
\hline & Friday & 6 & 1.6 \\
\hline & Saturday & 11 & 3 \\
\hline & Sunday & 10 & 2.7 \\
\hline & Don't remember & 58 & 15.6 \\
\hline \multirow{13}{*}{$\begin{array}{l}\text { How did you respond to the } \\
\text { incident? }\end{array}$} & No action & 15 & 11.5 \\
\hline & Told person to stop & 8 & 6.2 \\
\hline & Told friends/family & 7 & 5.4 \\
\hline & Told colleague & 2 & 1.5 \\
\hline & Transferred & 3 & 2.3 \\
\hline & help from union & 47 & 14.6 \\
\hline & $\begin{array}{l}\text { Completed incident } \\
\text { Form }\end{array}$ & 9 & 6.9 \\
\hline & $\begin{array}{l}\text { Defend self } \\
\text { physically }\end{array}$ & 18 & 13.8 \\
\hline & Counseling & 4 & 3.1 \\
\hline & Report to senior staff & 5 & 3.8 \\
\hline & $\begin{array}{l}\text { Help from } \\
\text { association }\end{array}$ & 4 & 3.1 \\
\hline & Prosecution & 9 & 6.9 \\
\hline & Others & 1 & 0.8 \\
\hline \multirow{2}{*}{$\begin{array}{l}\text { Do you think the incident } \\
\text { could have been prevented? }\end{array}$} & Yes & 64 & 17.3 \\
\hline & No & 68 & 18.3 \\
\hline \multirow{2}{*}{$\begin{array}{l}\text { Were you injured as a result of } \\
\text { the abuse incident? }\end{array}$} & Yes & 10 & 2.7 \\
\hline & No & 122 & 32.9 \\
\hline \multirow{2}{*}{$\begin{array}{l}\text { IF YES, did you require } \\
\text { formal treatment for the } \\
\text { injuries? }\end{array}$} & Yes & 8 & 2.2 \\
\hline & No & 2 & 0.5 \\
\hline \multirow{2}{*}{$\begin{array}{l}\text { Did you have to take time off } \\
\text { from work after being } \\
\text { attacked? }\end{array}$} & Yes & 15 & 4 \\
\hline & No & 117 & 31.6 \\
\hline \multirow[t]{2}{*}{ If yes, for how long? } & One day & 2 & 0.5 \\
\hline & $2-3$ weeks & 13 & 3.5 \\
\hline \multirow{3}{*}{$\begin{array}{l}\text { Was any action taken to } \\
\text { investigate the causes of the } \\
\text { incident? }\end{array}$} & Yes & 80 & 21.6 \\
\hline & No & 48 & 12.9 \\
\hline & Don't know & 4 & 1.1 \\
\hline \multirow{3}{*}{$\begin{array}{l}\text { Did your employer or } \\
\text { supervisor offer to provide } \\
\text { you with counselling }\end{array}$} & Yes & 27 & 7.3 \\
\hline & No & 94 & 25.4 \\
\hline & Don't know & 11 & 3 \\
\hline
\end{tabular}




\begin{tabular}{|c|c|c|c|}
\hline \multirow{2}{*}{$\begin{array}{l}\text { Did your employer or } \\
\text { supervisor offer to provide } \\
\text { you with other support? }\end{array}$} & Yes & 74 & 20.0 \\
\hline & No & 58 & 15.7 \\
\hline \multirow{5}{*}{$\begin{array}{l}\text { How satisfied are you with the } \\
\text { manner in which the incident } \\
\text { was handled? }\end{array}$} & Very dissatisfied & 51 & 13.7 \\
\hline & Dissatisfied & 27 & 7.3 \\
\hline & Neutral & 23 & 6.2 \\
\hline & Satisfied & 30 & 8.1 \\
\hline & Very satisfied & 1 & 0.3 \\
\hline \multirow{6}{*}{$\begin{array}{l}\text { If you did not report or tell } \\
\text { about the incident to others, } \\
\text { why not? }\end{array}$} & Not important & 26 & 7 \\
\hline & Ashamed & 17 & 4.6 \\
\hline & Guilty & 38 & 10.3 \\
\hline & $\begin{array}{l}\text { Afraid of the } \\
\text { consequences }\end{array}$ & 28 & 7.5 \\
\hline & Useless & 20 & 5.4 \\
\hline & Others & 3 & 0.8 \\
\hline \multirow{2}{*}{$\begin{array}{l}\text { In the last } 12 \text { months, have } \\
\text { you witnessed incidents of } \\
\text { physical abuse in your } \\
\text { workplace? }\end{array}$} & Yes & 87 & 23.5 \\
\hline & No & 262 & 70.6 \\
\hline \multirow{5}{*}{$\begin{array}{l}\text { If YES, how often has this } \\
\text { occurred in the last } 12 \\
\text { months? }\end{array}$} & Once & 38 & 10.2 \\
\hline & $2-4 x$ & 33 & 8.9 \\
\hline & $5-10 x$ & 4 & 1.1 \\
\hline & $\begin{array}{l}\text { Several times a } \\
\text { month }\end{array}$ & 10 & 2.7 \\
\hline & Daily & 2 & 0.5 \\
\hline \multirow{2}{*}{$\begin{array}{l}\text { Have you reported an incident } \\
\text { of workplace violence in the } \\
\text { last } 12 \text { months? (Witnessed or } \\
\text { experienced)? }\end{array}$} & Yes & 60 & 16.4 \\
\hline & No & 310 & 83.6 \\
\hline
\end{tabular}

In terms of the remaining abuse, in Table 4 , more than $50 \%$ of the population reported they had experiences of verbal abuses. A third of them felt they were sometimes verbally abused, but not that too often. According to the respondents, these verbal abuses were perpetrated by the patients $(27.5 \%)$ and their relatives $(16.7 \%)$ inside the hospital (51.6\%). Unlike physical ones, verbal abuses were not reported to the union. Instead, they were reported to their friends and loved ones $(25.9 \%)$. When reported to the hospital administration, there were no counselling done.

\section{Verbal Abuse}

Table 4: Incidents of Verbal Abuses Committed Against the Respondents

\begin{tabular}{|c|c|c|c|}
\hline & & FREQUENCY & PERCENTAGE \\
\hline \multirow{2}{*}{$\begin{array}{l}\text { In the last } 12 \text { months, } \\
\text { have you been } \\
\text { verbally abused in } \\
\text { your workplace? }\end{array}$} & Yes & 193 & 52.1 \\
\hline & No & 177 & 47.9 \\
\hline \multirow{4}{*}{$\begin{array}{l}\text { How often have you } \\
\text { been verbally abused } \\
\text { in the last } 12 \text { months? }\end{array}$} & No Answer & 177 & 47.9 \\
\hline & All the Time & 41 & 11.1 \\
\hline & Sometimes & 93 & 25.1 \\
\hline & Once & 59 & 15.9 \\
\hline \multirow{7}{*}{$\begin{array}{l}\text { Please think of the } \\
\text { last time you were } \\
\text { verbally abused in } \\
\text { your place of work. } \\
\text { Who verbally abused } \\
\text { you? }\end{array}$} & No Answer & 177 & 47.9 \\
\hline & Patient/Client & 102 & 27.5 \\
\hline & Relatives & 62 & 16.7 \\
\hline & Staff & 26 & 7.0 \\
\hline & Manager & 1 & 0.3 \\
\hline & Physician & 1 & 0.3 \\
\hline & General Public & 1 & 0.3 \\
\hline \multirow{4}{*}{$\begin{array}{l}\text { Where did the verbal } \\
\text { abuse take place? }\end{array}$} & No Answer & 177 & 47.9 \\
\hline & Inside & 191 & 51.6 \\
\hline & Patient's Home & 2 & 0.5 \\
\hline & Outside & 0 & 0 \\
\hline \multirow{14}{*}{$\begin{array}{l}\text { How did you respond } \\
\text { to the verbal abuse? } \\
\text { Please tick all } \\
\text { relevant boxes }\end{array}$} & Defend myself & 2 & 0.5 \\
\hline & No Action & 35 & 9.4 \\
\hline & $\begin{array}{l}\text { Pretend Never } \\
\text { Happened }\end{array}$ & 3 & 0.8 \\
\hline & Told Person to Stop & 20 & 5.4 \\
\hline & Told Friends/Family & 96 & 25.9 \\
\hline & Told Colleague & 1 & 0.3 \\
\hline & Report to Senior Staff & 3 & 0.8 \\
\hline & Counselling & 20 & 5.4 \\
\hline & Help from Union & 5 & 1.4 \\
\hline & Help from Association & 0 & 0 \\
\hline & Transferred & 3 & 0.8 \\
\hline & $\begin{array}{l}\text { Completed Incident } \\
\text { Form }\end{array}$ & 0 & 0 \\
\hline & Prosecution & 0 & 0 \\
\hline & $\begin{array}{c}\text { Completed } \\
\text { Compensation }\end{array}$ & 5 & 1.3 \\
\hline \multirow{3}{*}{$\begin{array}{l}\text { Do you think the } \\
\text { incident could have } \\
\text { been prevented? }\end{array}$} & No answer & 177 & 47.9 \\
\hline & Yes & 101 & 27.2 \\
\hline & No & 92 & 24.8 \\
\hline \multirow{3}{*}{$\begin{array}{l}\text { Was any action taken } \\
\text { to investigate the } \\
\text { causes of the verbal } \\
\text { abuse? }\end{array}$} & No answer & 177 & 47.9 \\
\hline & Yes & 81 & 21.8 \\
\hline & No & 103 & 27.8 \\
\hline
\end{tabular}




\begin{tabular}{|c|c|c|c|}
\hline $\begin{array}{l}\text { If NO or DON'T } \\
\text { KNOW, please go to } \\
\text { question VA } 8\end{array}$ & I don't know & 9 & 2.4 \\
\hline \multirow{7}{*}{$\begin{array}{l}\text { If YES, by whom: If } \\
\text { YES, what were the } \\
\text { consequences for the } \\
\text { abuser? }\end{array}$} & None & 177 & 47.9 \\
\hline & Management/Employer & 61 & 16.4 \\
\hline & Union & 1 & 0.3 \\
\hline & Association & 11 & 3 \\
\hline & Community Group & 0 & 0.0 \\
\hline & Police & 7 & 1.9 \\
\hline & Others & 1 & 0.3 \\
\hline \multirow{7}{*}{$\begin{array}{l}\text { If YES, what were the } \\
\text { consequences for the } \\
\text { abuser? }\end{array}$} & None & 34 & 39.5 \\
\hline & verbal warning issued & 11 & 2.9 \\
\hline & care dc & 11 & 2.9 \\
\hline & reported to police & 1 & 0.3 \\
\hline & aggressor prosecuted & 10 & 2.7 \\
\hline & others & 9 & 2.4 \\
\hline & don't know & 5 & 1.4 \\
\hline \multirow{3}{*}{$\begin{array}{l}\text { Did your employer or } \\
\text { supervisor offer to } \\
\text { provide you with: } \\
\text { Counselling }\end{array}$} & No answer & 177 & 47.9 \\
\hline & Yes & 19 & 5.1 \\
\hline & No & 174 & 46.9 \\
\hline \multirow{3}{*}{$\begin{array}{l}\text { Opportunity to speak } \\
\text { about/report }\end{array}$} & No answer & 177 & 47.9 \\
\hline & Yes & 133 & 35.8 \\
\hline & No & 60 & 16.3 \\
\hline \multirow[t]{3}{*}{ Other support? } & No answer & 177 & 47.9 \\
\hline & Yes & 71 & 19.2 \\
\hline & No & 122 & 32.8 \\
\hline \multirow{6}{*}{$\begin{array}{l}\text { How satisfied are you } \\
\text { with the manner in } \\
\text { which the incident } \\
\text { was handled? }\end{array}$} & No Answer & 177 & 47.9 \\
\hline & Very Dissatisfied & 9 & 2.4 \\
\hline & Dissatisfied & 23 & 6.2 \\
\hline & Neutral & 128 & 34.4 \\
\hline & Satisfied & 29 & 7.8 \\
\hline & Very Satisfied & 4 & 1.0 \\
\hline \multirow{7}{*}{$\begin{array}{l}\text { If you did not report } \\
\text { or tell about the } \\
\text { incident to others, } \\
\text { why not? }\end{array}$} & No Answer & 177 & 47.9 \\
\hline & Not Important & 57 & 15.3 \\
\hline & Ashamed & 45 & 12.1 \\
\hline & $\begin{array}{l}\text { Afraid of Negative } \\
\text { Consequences }\end{array}$ & 19 & 5.1 \\
\hline & $\begin{array}{c}\text { Did Not Know Who to } \\
\text { Report }\end{array}$ & 2 & 0.5 \\
\hline & Useless & 26 & 7 \\
\hline & Others & 44 & 11.8 \\
\hline
\end{tabular}

Correlation between Demographic Data and Physical Abuse, Verbal Abuse, Depression, Anxiety, and Stress

In establishing relationship with physical abuse, Table 5 shows that $66.4 \%$ of the self-reported cases of physical abuse can be attributed to working in certain hospitals. This suggests that the overall hospital setting may influences condition for vulnerability to physical abuse. In establishing relationship with verbal abuse, in certain hospitals, vulnerability to verbal abuse is often greater since $98.4 \%$ of the variance can be explained by this variable. For stress, highest percentage attribution is at $14.3 \%$ owing to the hospital, followed by $13.4 \%$ because of job experience. For depression, highest percent attribution is at $17.6 \%$ associated with hospitals where they worked and job experience at $11.6 \%$ and age $11.5 \%$. In anxiety, the percentage attribution is highest with hospital $18.8 \%$, and age $15.3 \%$.

In associating abuse and psychological health status, results showed that in attribution of stress with physical abuse (15.3\%) and verbal abuse (11.0\%) compared with anxiety and depression. In terms of anxiety, the attribution to physical abuse were $3.4 \%$ and $4.3 \%$ for verbal abuse, respectively. The same trends were seen with depression at $5.2 \%$ for physical abuse and $2.8 \%$ with verbal abuse. It must be considered that the correlation of variables registered at the range of $1.8 \%$ to $18.8 \%$ are considered lower percentage attribution. This implies that the association of variables cannot be derived. Also, among these demographic variables, job of the respondents was noted as not applicable or $\mathrm{n} / \mathrm{a}$ since all staff who answered the survey were nurses and no other type of professionals.

Table 5: Percentage Variance of the Physical and Verbal Abuse, Stress, Anxiety, and Depression Attributed to Selected Demographic Variables

\begin{tabular}{|l|l|c|c|}
\hline & & Eta & $\begin{array}{c}\% \\
\text { Variance } \\
\text { Explained }\end{array}$ \\
\hline 1. Hospital & Physical Abuse & 0.664 & $66.40 \%$ \\
\hline & Verbal Abuse & 0.984 & $98.40 \%$ \\
\hline & Stress & 0.143 & $14.30 \%$ \\
\hline & Anxiety & 0.188 & $18.80 \%$ \\
\hline 2. Age & Depression & 0.176 & $17.60 \%$ \\
\hline & Physical Abuse & 0.142 & $14.20 \%$ \\
\hline
\end{tabular}




\begin{tabular}{|c|c|c|c|}
\hline & Verbal Abuse & 0.178 & $17.80 \%$ \\
\hline & Stress & 0.08 & $8.00 \%$ \\
\hline & Anxiety & 0.153 & $15.30 \%$ \\
\hline & Depression & 0.115 & $11.50 \%$ \\
\hline \multirow[t]{5}{*}{ 3. Gender } & Physical Abuse & 0.099 & $9.90 \%$ \\
\hline & Verbal Abuse & 0.13 & $13.00 \%$ \\
\hline & Stress & 0.056 & $5.60 \%$ \\
\hline & Anxiety & 0.103 & $10.30 \%$ \\
\hline & Depression & 0.093 & $9.30 \%$ \\
\hline \multirow[t]{5}{*}{$\begin{array}{l}\text { 4. Marital } \\
\text { Status }\end{array}$} & Physical Abuse & 0.076 & $\begin{array}{c}1 \\
7.60 \%\end{array}$ \\
\hline & Verbal Abuse & 0.101 & $10.10 \%$ \\
\hline & Stress & 0.048 & $4.80 \%$ \\
\hline & Anxiety & 0.091 & $9.11 \%$ \\
\hline & Depression & 0.081 & $8.10 \%$ \\
\hline \multirow[t]{5}{*}{ 5. Job* } & Physical Abuse & $\mathrm{Na}$ & $\mathrm{Na}$ \\
\hline & Verbal Abuse & $\mathrm{Na}$ & $\mathrm{Na}$ \\
\hline & Stress & $\mathrm{Na}$ & $\mathrm{Na}$ \\
\hline & Anxiety & $\mathrm{Na}$ & $\mathrm{Na}$ \\
\hline & Depression & $\mathrm{Na}$ & $\mathrm{Na}$ \\
\hline \multirow[t]{5}{*}{$\begin{array}{l}\text { 6. Job } \\
\text { Experience }\end{array}$} & Physical Abuse & 0.059 & $5.90 \%$ \\
\hline & Verbal Abuse & 0.125 & $12.50 \%$ \\
\hline & Stress & 0.134 & $13.40 \%$ \\
\hline & Anxiety & 0.137 & $13.70 \%$ \\
\hline & Depression & 0.116 & $11.60 \%$ \\
\hline \multirow[t]{3}{*}{ 7. Job Shift } & Physical Abuse & 0.029 & $2.90 \%$ \\
\hline & Verbal Abuse & 0.006 & $6.00 \%$ \\
\hline & Stress & 0.120 & $12.00 \%$ \\
\hline
\end{tabular}

\begin{tabular}{|l|c|c|c|}
\hline & Anxiety & 0.085 & $8.50 \%$ \\
\hline & Depression & 0.038 & $3.80 \%$ \\
\hline $\begin{array}{l}\text { 8. Physical } \\
\text { abuse }\end{array}$ & Stress & 0.153 & $15.30 \%$ \\
\hline & Anxiety & 0.034 & $3.40 \%$ \\
\hline & Depression & 0.520 & $5.20 \%$ \\
\hline $\begin{array}{l}\text { 9. Verbal } \\
\text { abuse }\end{array}$ & Stress & 0.110 & $11.00 \%$ \\
\hline & Anxiety & 0.043 & $4.30 \%$ \\
\hline & Depression & 0.028 & $2.80 \%$ \\
\hline
\end{tabular}

\section{DISCUSSION}

Results showed that more than fifty percent of the selected hospital nurses $(>50 \%)$ experienced verbal abuse. Verbal abuse among several studies showed that there were $38 \%$ among nurses in a study in United States (Nachriener et al., 2007) and 37\% in Jordan (Ahmed, 2012). A study in a university hospital in Saudi Arabia showed that the frequency of verbal abuse was lesser than physical abuse which were also experienced by nurses in a study in Iraq which is about $42 \%$ (AbuAlRub et al. 2011). Results also showed that physical abuse is lesser than verbal abuse but accounts to more than thirty percent of the cases $(>30 \%)$. Khademloo, Mononesi \& Gholizade (2013) revealed similar pattern wherein nurses in Northern Iran. A similar pattern also resulted in Jordan whereby $52.8 \%$ were physically abused and 67.85 experienced verbal forms (Al-Omari, 2015). It is typical that physical abuse occurs when verbal violence is not well managed. Perpetrators will do physical attack due to pent up emotions when verbal expressions are not enough to address their concerns about the circumstances with their health.

Results showed that both patients and their relatives were among the common perpetrators regardless of the forms of abuse. This is similar to the findings in Northern Iran (Khademloo, Moonesi \& Gholizade, 2013). The parents and significant family members wanted to receive the right treatment so whenever their needs are not addressed well, conflict will escalate and can lead to abuse or workplace violence (Lin \& Liu, $2005)$. Both the working environment and nurses may 
also trigger the workplace violence. Nurses skills, behavior and anxiety may have led to capricious situations leading to unwanted circumstances (Chen et al., 2008; Lyneham, 200; Pai \& Lee, 2011).

This study showed that in physical abuse, most of the nurses refer to the union as the case seemed more dangerous and needs utmost attention than verbal abuse. Most nurses tell their peers and friends about verbal abuse experience than report to the union or organization. In contrast, a study in Jordan showed that nurses who experience either form of abuse tells the predator to stop rather than reporting to union (AlOmari, 2015). Nurses are in stressful situations in clinical settings whereby they are exposed to accidents, deaths, different health care specialties like physicians, and patient-related activities. This situation predisposes nurses to abuse from the patients and other individuals they are working with (Islam, 2003). Previous studies supported that the prevalence rate of abuse among nurses ranged from $37 \%$ to $72 \%$ (Lin et al., 2005; Stirling et al., 2001). Results of this study again showed that $34 \%$ to $53 \%$ experienced abuse. Previous study reported that injuries and violence toward nurses continue to be major issues in hospitals (Unruh \& Asi, 2006). Hence, these findings imply that meaningful safety programs for nurses should be addressed by the organization. These programs and procedures should ensure protection to nurses from violence and prevent any form of abuse to nurses.

Results of this study showed that nurses do not experience any of these mental health concerns when compared to the variations. Compared to depression and stress, nurses experienced anxiety as the most common. Both anxiety and depression have an overall prevalence of more than $50 \%$. In stress, there were hospital nurses who experienced only mild and moderate. In Hong Kong, Cheung \& Yip (2015) showed that hospital nurses have an overall stress prevalence of $41.1 \%$ compared to $29.5 \%$ in this study in Saudi Arabia. In both primary and tertiary health care settings in Saudi Arabia, nurses experience stress primarily due to workload and that both lack of support and uncertainty concerning treatment were other common reasons. Nurses occupational stress is more common among nurses in the hospital than in primary care settings (Alenezi, Aboshaiqah \& Baker, 2018). The occupational stress negatively affects not only psychological but also the physical health status of the person (McKinney, 2011). Several studies showed that in nursing profession nowadays, work-related stress is a prevailing concern which could affect nursing turnover, casual and sick leaves, disengagement, dissatisfaction, and absenteeism (Demerouti, Bakker, Nachreiner \& Schaufeli, 2000; Foglia, Grassley \& Zeigler, 2010; Happell et al., 2013). Chronic stress will impact both patient and the image of the organization (Hallsten et al., 2011; Nayeri, Saheli \& Noghabi, 2011). Allister \& Kinno (2009) explained that nurses encounter stress because of permanent confrontation with patients, tasks were more focused with human health, job performance were clinical, exposure to death, dealing with emergency and unpredictable situations, workplace pollution, and staffing problems. In Japan, nurses were found to be at risk to high number of stressors compared to other professionals (Kawano, 2008).

Results showed that those hospital nurses only experienced mostly mild and moderate forms of anxiety. The overall anxiety prevalence in this study in Saudi Arabia is $63.0 \%$ compared to nurses in Hong Kong which is $37.3 \%$ (Cheung \& Yip, 2015). On the other hand, the results showed the hospitals nurses have either mild, moderate, and severe forms of depression. The overall depression prevalence in this study is $56.5 \%$ whereas in Hong Kong data revealed 35.8\% (Cheung \& Yip, 2015). A study showed that some nurses in Australia are confronted with sleeping problems (Perry et al., 2015). Rest and sleep are uncommon in clinical nurses because of the demands, shift, and other work issues related to the nursing assignments (Cheung \& Yip, 2015). Depression must be addressed as this has been considered as one of the major medical and social issues which can impact labor, economy, and social empowerment (Steger \& Kashdan, 2009; Obrien, Kenedy \& Ballard, 2012). The cases of depression can lower resources which can lead to financial loss (Obrien, Kenedy \& Ballard, 2012). When nurses cause harm to the patients and the hospitals, it is the organization that will pay the cost (You et al., 2013). Previous studies showed that nurses are among the working group that often encounter mental health problems. The psychological manifestations of nurses are exhibited by signs and symptoms of stress, anxiety, and depression (Taghva et al., 2013). Stress, anxiety, and depression can lead to low self-confidence and recurrent absenteeism. Hence, the health status of the nurses can affect the quality of nursing care services and the satisfaction of the patients (Kawano, 2008).

Correlation tests showed that physical and verbal 
abuse can be attributed to working in hospitals. The overall hospital setting sets the condition for vulnerability to abuse. In certain hospitals, vulnerability to verbal abuse is often greater whereby similar patterns were shown in Northern Iran and Jordan (Al-Omari, 2015; Khademloo, Moonesi \& Gholizade, 2013). The findings of this study are in contrast with other published studies about abuse and the demographic factors of the nurses like in Jordan (Al-Omrani, 2015). The study of Al-Omari (2005) showed that females are more verbally attacked than men whereby gender was not found as significantly associated with abuse in this study. It could have been substantiated that since both Saudi Arabia and Jordan follows patriarchal system, then power and decisions are more inclined to men than women. The females with higher educational degree are reportedly more abused than their counterparts.

This study found that stress showed higher attribution to working in certain hospitals. The hospitals which housed health care professionals' everyday encounter human communication and health-related issues which can trigger stress. Burnout has been evidently shown as a global issue among nurses due to their hospital work (Mousavi et al., 2017). Similar findings showed that stress can be attributed to the nurses' status in terms of job experience. Alenezi, Aboshaiqah \& Baker (2018) found out that the stress reported by hospital nurses in Saudi Arabia were significantly correlated with job position and other demographic data. The contrasting results can be due to the distinction of the regions where the study was conducted in Saudi Arabia.

Furthermore, results showed that there was no direct link between physical and verbal abuse with stress, anxiety, and depression. Several published studies showed that experiencing abuse can somehow aggravate the nurses' stress, anxiety, and depression. The abuse on nurses in the workplace can lead to psychological consequences such as anger, disappointment, anxiety, self-doubt, insecurity, and loss of confidence (Franz et al., 2010; Kamchuchat et al., 2008). In Iran, study showed that mental health can positively affect the demonstration of professionalism of nurses hence trainings on emotion control must be promoted among nurses. Burnout is prominent among hospitals nurses with depression and anxiety than just experiencing stress (Mousavi et al., 2017). Moreover, aggressions can affect the health status of the nurses (Fujishiro, Gee \& de Castro, 2010). Workplace aggression are associated with increased risks of poor general health and can adversely affect the work-related health outcomes. Overall, this study and relevant literature provided empirical basis in developing interventional programs that can have meaningful impact towards nurses' safety from the unwanted circumstances in their workplace like abuse.

\section{Limitations}

The use of DASS 21 limits to its screening power and is not for diagnostic purposes. The tool does not account for the experiences after the recognized period of 1 week before screening. The research design used only established association of variables, meaning that both verbal and physical abuse are not causative factors. The nurses were selected using convenience techniques; thus, the results cannot be generalized to all nurses in Saudi Arabia nor Hafer-Albatain.

\section{CONCLUSION}

Both physical and verbal abuse among nurses occur in several hospitals in Hafer-Albatain wherein verbal forms were most common. Also, anxiety is the most prevalent mental health concern among nurses than depression and stress. The hospital setting is significantly correlated with the type of abuse and occupational stress. Thus, strengthening peer support and establishing shared decision-making in policies needed to prevent abuse. Shared efforts in creating a healthy working environment may be planned and implemented in all these hospital units. Promoting engagement between the staff, patient, and families are recommended so that conflict will be avoided and that nurses will have a positive psychological health status.

\section{Conflict of Interests}

The authors declare that they have no conflict of interest.

\section{ACKNOWLEDGEMENT}

The authors are thankful to the institutional authority for completion of the work.

\section{REFERENCES}

Abbas, M.A.F., Abu Zaid, L.Z., Hussaein, M., Bakheet, K.H. \& AlHamdan, N.A. (2012). Anxiety and depression among nursing staff at King Fahad Medical City, Kingdom of Saudi Arabia. Journal of American Science, 8(10), pp 
778-794.

AbuAlRub, R.F. \& Al-Asmar, A.H. (2011). Physical violence in the workplace among Jordanian hospital nurses. Journal of Transcultural Nursing, 22(2), pp 157-165.

Ahmed, A.S. (2012). Verbal and physical abuse against Jordanian nurses in the work environment. Eastern Mediterranean Health Journal, 18(4), pp 318-324.

Ahmed, W.A.M. (2015). Anxiety and related symptoms among critical care nurses in Albaha, Kingdom of Saudi Arabia. AIMS Medical Science, 2(4), pp 303-309.

Alameddine, M., Mourad, Y. \& Dimassi, H. (2015). A national study on nurses' exposure to occupational violence in Lebanon: Prevalence, consequences, and associated factors. PloS ONE, 10(9).

Alenezi, A.M., Aboshaiqah, A. \& Baker, O. (2018). Work-related stress among nursing staff working in government hospitals and primary health care centres. International Journal of Nursing Practice, 24(5).

Aljuhaili, W.M. \& Alzghool, M.M. (2020). Determining the influence of life change events on the mental health nurses: A case of Saudi Arabia. Global Journal of Health Science, 12(3), pp 45- 54.

Alkorashy, H.A.E. \& Al Moalad, F.B. (2016). Workplace violence against nursing staff in a Saudi university hospital. International Nursing Review, 63(2), pp 226-232.

Alister, M. \& Kinno, J. (2009). The important of teaching and learning resilience in the health disciplines: a critical review of the literature. Nurse Education Today, 29(4), pp 371-379.

Ahmed, W.A.M. (2015). Anxiety and related symptoms among critical care nurses in Albaha, Kingdom of Saudi Arabia. AIMS Medical Science, 2(4), pp 303-309.

Al-Omari, H. (2015). Physical and verbal workplace violence against nurses in Jordan. International Nursing Review, 62(1), pp 111-118.

Al-Shamlan, N.A., Jayaseeli, N., Al-Shawi, M.M. \& Al-Joudi, A.S. (2017). Are nurses verbally abused? A crosssectional study of nurses at a university hospital, Eastern Province, Saudi Arabia. Journal of Family \& Community Medicine, 24(3), pp 173.

Al-Turki, N., Afify, A.A. \& AlAteeq, M. (2016). Violence against health workers in Family Medicine Centers. Journal of Multidisciplinary Healthcare, 9, pp 257.

Brous, E. (2018). Workplace Violence. Legal Clinic, 118 (10), pp 51-55.

Campbell, A.F. (2016). Why violence against nurses has spiked in the last decade. The Atlantic. Retrieved from: https://www.theatlantic. com/business/archive/2016/12/violence-against-nurses/509309

Chen, W.C., Sun, Y.H., Lan, T.H. \& Chiu, H.J. (2008) Incidence and risk factors of workplace violence on nursing staffs caring for chronic psychiatric patients in Taiwan. International Journal of Environment Research and Public Health, 6(11), pp 2812-2821.

Cheung, T. \& Yip, P. (2015). Depression, anxiety and symptoms of stress among Hong Kong nurses: a cross-sectional study. International Journal of Environmental Research and Public Health, 12(9), pp 11072-11100.

Demerouti, E., Bakker, A.B., Nachreiner, F. \& Schaufeli, W.B. (2000). A model of burnout and life satisfaction amongst nurses. Journal of Advanced Nursing, 32(2), pp 454-464.

El-Gilany, A.H., El-Wehady, A. \& Amr, M. (2010). Violence against primary health care workers in Al-Hassa, Saudi Arabia. Journal of Interpersonal Violence, 25(4), pp 716-734.

Fjelland, J., Barron, C. \& Foxall, M. (2007). A review of instruments measuring two aspects of meaning: Search for meaning and meaning in illness. Journal of Advanced Nursing, 62(4), pp 394-406. 
Foglia, D.C., Grassley, J.S. \& Zeigler, V.L. (2010). Factors that influence pediatric intensive care unit nurses to leave their jobs. Critical Care Nursing Quarterly, 33(4), pp 302-316.

Franz, S., Zeh, A., Schablon, A., Kuhnert, S. \& Nienhaus, A. (2010). Aggression and violence against health care workers in Germany-a cross sectional retrospective survey. BMC Health Services Research, 10(1), pp 51.

Fujishiro, K., Gee, G. C. \& de Castro, A. B. (2011). Associations of workplace aggression with work-related well-being among nurses in the Philippines. American Journal of Public Health, 101(5), pp 861-867.

Fute, M., Mengesha, Z.B., Wakgari, N. \& Tessema, G.A. (2015). High prevalence of workplace violence among nurses working at public health facilities in Southern Ethiopia. BMC Nursing, 14(1), pp 9.

Grossman, M., Lee, V., Kenny, J., McHarg, L., Godin, M. \& Chambers, J. (2000). Psychological adjustment of critically injured patients three months after an unexpected, potentially life-threatening accident. Journal of Clinical Nursing, 9, pp 801-815.

Hallsten, L., Voss, M., Stark, S. \& Josephson, M. (2011). Job burnout and job wornout as risk factors for long-term sickness absence. Work, 38(2), pp 181-192.

Happell, B., Dwyer, T., Reid-Searl, K., Burke, K.J., Caperchione, C. M. \& Gaskin, C. J. (2013). Nurses and stress: Recognizing causes and seeking solutions. Journal of Nursing Management, 21(4), pp 638-647.

Hegney, D., Plank, A. \& Parker, V. (2003) Workplace violence in nursing in Queensland, Australia: A self-reported study. International Journal of Nursing Practice, 9, pp 261-268.

Hesketh, K.L., Duncan, S.M., Estabrooks, C.A., Reimer, M.A., Giovannetti, P., Hyndman, K. \& Acorn, S. (2003). Workplace violence in Alberta and British Columbia hospitals. Health Policy, 63(3), pp 311-321.

Islam, S.S., Edla, S.R., Mujuru, P., Doyle, E.J. \& Ducatman, A.M. (2003). Risk factors for physical assault: state managed workers' compensation experience. American Journal of Preventive Medicine, 25, pp 31-37.

Kamchuchat, C., Chongsuvivatwong, V., Oncheunjit, S., Yip, T.W. \& Sangthong, R. (2008). Workplace violence directed at nursing staff at a general hospital in southern Thailand. Journal of Occupational Health, 50(2), pp 201207.

Kawano, Y. (2008). Association of job-related stress factors with psychological and somatic symptoms among Japanese hospital nurses: effect of departmental environment in acute hospitals. Journal of Occupational Health, 50(1), pp 79-85.

Khademloo, M., Moonesi, F. S. \& Gholizade, H. (2013). Health care violence and abuse towards nurses in hospitals in north of Iran. Global Journal of Health Science, 5(4), pp 211.

Li, P., Xing, K., Qiao, H., Fang, H., Ma, H., Jiao, M., Hao, Y., Li, Y., Liang, L., Gao, L. \& Kang, Z. (2018). Psychological violence against general practitioners and nurses in Chinese township hospitals: incidence and implications. Health and Quality of Life Outcomes, 16(1), pp 117.

Lin, Y. \& Liu, H. (2005). The impact of workplace violence on nurses in South Taiwan. International Journal of Nursing Studies, 42, pp 773-778.

McKinney, B. K. (2011). Withstanding the pressure of the profession. Journal for Nurses in Staff Development, 27, pp 69-73.

Mousavi, S.V., Ramezani, M., Salehi, I., Hossein Khanzadeh, A.A. \& Sheikholeslami, F. (2017). The relationship between burnout dimensions and psychological symptoms (depression, anxiety, and stress) among nurses. Journal of Holistic Nursing and Midwifery, 27(2), pp.37-43.

Nachreiner, N.M., Gerberich, S.G., Ryan, A.D. \& McGovern, P.M. (2007). Minnesota nurses' study: perceptions of violence and the work environment. Industrial Health, 45, pp 672-678. 
National Nurses United (2016). National Nurses United petitions federal OSHA for workplace violence prevention standard. Retrieved from: https://www.nationalnursesunited.org/ press/national-nurses-united-petitions-federalosha-workplaceviolence-prevention-standard

Nayeri, N., Saheli, T. \& Noghabi, A. (2011). Quality of work life and productivity among Iranian nurses. Contemporary Nurse, 9(1), pp 106-118.

Obrien, P.G., Kenedy, W.Z. \& Ballard, K.A. (2012). Psychiatric Mental Health Nursing: An Introduction to Theory and Practice. $2^{\text {nd }}$ Edition. USA: Jones \& Bartlett Learning.

Pai, H. \& Lee, S. (2011). Risk factors for workplace violence in clinical registered nurses in Taiwan. Journal of Clinical Nursing, 20, pp 1405-1412.

Perry, L., Lamont, S., Brunero, S., Gallagher, R. \& Duffield, C. (2015). The mental health of nurses in acute teaching hospital settings: A cross-sectional survey. BMC Nursing, 14, pp 1-8.

Robert Wood Johnson Foundation (2015). Nurses face epidemic levels of violence at work. Retrieved from: https://www.rwjf.org/en/library/articles-and-news/2015/07/ nurses-face-epidemic-levels-of-violence-atwork.html

Rowe, M.M. \& Sherlock, H. (2005). Stress and verbal abuse in nursing: do burned out nurses eat their young?. Journal of Nursing Management, 13, pp 242-248.

Steger, M. \& Kashdan, T. (2009). Depression and Everyday Social Activity, Belonging, and Well-Being. Journal of Counseling Psychology, 56(2), pp 289-300.

Stirling, G., Higgins, J. E. \& Cooke, M. W. (2001). Violence in A\&E departments: a systematic review of the literature. Accident and Emergency Nursing, 9, pp 77-85.

Taghva, A, Yazdani, A., Ebrahimi, M.R., Alizadeh, K. \& Sakhabakhsh, M. (2013). Prevalence of depression in psychiatric Nurses and comparison with other parts of the AJA hospitals. Journal of Nurse and Physician within War, 23(24), pp 11-16.

Unruh, L. \& Asi, Y. (2018). Determinants of workplace injuries and violence among newly licensed RNs. Workplace Health \& Safety, 66(10), pp 482-492.

World Health Organization. (2002). Framework guidelines for addressing Workplace Violence in the Health Sector. Retrieved from: http://www.who.int/violence_injury_prevention/injury/work9/en/

You, L.M., Aiken, L.H., Sloane, D.M., Liu, K., He, G.P., Hu, Y., Jiang, X.L., Li, X.H., Li, X.M., Liu, H.P. \& Shang, S.M. (2013). Hospital nursing, care quality, and patient satisfaction: cross-sectional surveys of nurses and patients in hospitals in China and Europe. International Journal of Nursing Studies, 50(2), pp 154-161. 